phys. Res. Commun., 46, 1956 ; 1972) have now applied this method to pronase, and find that the extent of the active site is such that it interacts with five successive residues on the substrate. Beyond this there is no measurable effect of sequence. In pepsin, Sachdev, Johnston and Fruton (Biochemistry, 11, 1080 ; 1972) have also shown that the affinity for substrate peptides depends acutely on the side chains near the vulnerable bond. This will presumably turn out to be a very general phenomenon.

\section{MYRIAPODOLOGY}

\section{Myriapods in Manchester}

from a Correspondent

IN his presidential address to the second international congress of myriapodology at the University of Manchester (April 5-12), Dr S. Graham Brade-Birks (Wye College, Kent) looked back over fifty years to the foundations laid by Brölemann, Verhoeff and Pocock, and forwards to an increasing awareness of the importance of myriapods in soil science. Delving still further back into one of the president's earlier fields of research, Professor O. Kraus (University of Hamburg) considered that Palaeozoic diplopods may have lived above ground, only later going to earth as cryptozoa, loosing their elaborate spines and fusing their sclerites into rigid cylinders. These "rings", according to $\mathrm{Dr}$ W. Dohle (Free University, Berlin), have a complex embryological origin. The first diplosegment (the fifth ring) encompasses the single pair of limbs of the fourth and the anterior pair of the first ventral diplosomite. Such an explanation, apparently highly improbable, he said, is, however, true. More highly improbable schemes of the diplopod nature of "segments" in other groups were challenged by Dr S. M. Manton (British Museum (Natural History) and Queen Mary College, London) who furnished explanations of the extra tergites in Symphyla, and other departures from simple segmentation in chilopods, in functional terms, as devices facilitating turning, running or burrowing.

In a free discussion on phylogeny several schemes were examined. The scheme of Tiegs, which relates Pauropoda and Diplopoda as Dignatha and Chilopoda, Symphyla and Hexapoda as Trignatha found most favour, but $\mathrm{Dr}$ Manton argued emphatically against relating any myriapod with a hexapod group and urged caution in relating any two myriapod groups. Myriapods may be loosely connected by their jointed transversely biting mandibles, but are quite distinct from the insects with unjointed rolling mandibles.
Interrelations between species were also debated. Dr E. H. Eason (Moreton-in-Marsh, Gloucestershire) described the confusion which had arisen from the "lumping" of Attems and the "splitting" of Chamberlin and the odd zoogeography of the Lithobiidae which might follow. Dr C. A. W. Jeekel (Zoological Museum, University of Amsterdam) has revised the Sphaerotheriidae (giant pill millipedes) using secondary sexual characters, and has produced natural groupings more consistent with their discontinuous geographic distribution. One of the highlights of the congress was a recording of a stridulating male Sphaerotherium made by Dr U. Haacker (University of Hamburg) as part of his study of communication between potential mating pairs of millipedes. Dr Haacker showed the functional significance of many of the secondary sexual characters used by systematists.

Excellent contributions on the neurosecretory organs of diplopods were presented by French physiologists who have been largely responsible for opening-up this area of research. Professor F. Sahli (University of Dijon) reviewed his own work and that of his French and Indian colleagues and moved towards a synthesis. The cerebral glands (organes de Gabe) seem to be the histophysiological equivalents of the neurohaemal organs of the apterygote groups and the Symphyla; he compared the paraoesophageal bodies with the corpora cardiaca of pterygotes and tentatively suggested that the corps connectifs are analogues of the perisympathetic bodies of pterygotes.

Studies on post-embryonic development have been facilitated by the methods of stadium characterization developed by French workers. $\mathrm{Mr}$ J.-M. Demange (Muséum National d'Histoire Naturelle, Paris) presented some interesting thoughts on the increment of segments and ocelli added at each moult and reaffirmed his belief in Brölemann's theory of neotenic contraction. One of the practical results of this work is that in Manchester life tables have been constructed for several species which, along with feeding studies, confirm that a large part of the leaf fall in woodland is ingested and comminuted by millipedes. It is still difficult, however, to characterize the epimorphic stadia of pill millipedes, but this problem has been surmounted by Mr K. L. Bocock and his colleagues (Nature Conservancy, Merlewood Research Station, Lancashire). Most exasperating are the difficulties encountered in ageing blaniulids (thin snake millipedes), some of which are important pests of sugar beet.

More needs to be known about the ecology of these animals if sensible control measures are to be developed. Woodland millipedes are apparently more favoured subjects and there were three complementary contributions on Proteroiulus fuscus in woodland, one by an English and two by Finnish zoologists. International cooperation fostered by the Centre National de Myriapodologie in Paris assured the success of this symposium, the first to enjoy the sponsorship of the Zoological Society of London away from the capital.

\section{AGRICULTURE}

\section{Seed Ecology}

\section{from a Correspondent}

THE nineteenth annual Easter school in agricultural science, held at the University of Nottingham School of Agriculture at Sutton Bonington from April 17-20, had for its subject the wideranging topic of seed ecology. During the meeting, this topic was considered at all levels, ranging from the fundamental biochemistry of dormancy and

\title{
Arrangement of Ribosomal Proteins
}

IN next Wednesday's Nature New Biology (May 17) Kagawa, Jishuken and Tokimatsu describe an attempt to determine how the ribosomal proteins of the Escherichia coli $50 \mathrm{~S}$ subunits are arranged along the RNA chain. When the ribosomes are deprived of magnesium ions, they unfold to give extended, nuclease-labile particles. Kagawa et al. have digested these particles with ribonucleases $T_{1}$ and $I$, and separated the nucleoprotein fragments so produced by polyacrylamide gel electrophoresis.

The components in the mixture were then subjected to electrophoresis in the second dimension under solvent conditions leading to dissociation of the pro- teins from the RNA and each other. By this means the proteins present in particular fragments were identified. By using different concentrations of EDTA to bring about progressive unfolding, the extent of digestion can be controlled. Based on the results, the authors present a linear sequence of proteins, which is the presumed order in which they occur.

Not all components were resolved: the authors allocate twenty-six resolved 50 S ribosomal proteins to twelve positions along the RNA. No allowance is made for proteins binding to other proteins and not to RNA, and it has to be assumed that the unfolding process is not accompanied by any redistribution of proteins. 